\title{
Physiotherapy and Rehabilitation Bachelor's Degree Education in Turkey: Comparative Analysis of Curriculum between Foundation and State Universities
}

\author{
İpek ALEMDAROĞLU, Hülya Nilgün GÜRSES, Müberra TANRIVERDi \\ Department of Physiotherapy and Rehabilitation, Bezmialem Vakif University School of Medicine, İstanbul, Turkey
}

\section{ABSTRACT}

Objective: The purpose of our study was to analyze and reveal the similarities and differences between the curriculums of the physical therapy and rehabilitation (PTR) faculty departments/colleges (FD/C) in foundation and state universities in Turkey.

Methods: The student quotas and curriculums of PTR FD/Cs in foundation (Group 1) and state (Group 2) universities were reached. The number of FD/Cs and their student quotas were calculated. Curriculum parameters were investigated from the FD/Cs official websites and compared between groups.

Results: 64 universities were found to get permission to give PTR education, and 46 of these obtained student quotas in the 2014-2015 academic year. Curriculums of 41 out of $46 \mathrm{FD} / \mathrm{Cs}(89.1 \%)$ were reached from their websites. The only statistically significant difference was found in student quotas $(\mathrm{z}=-3.422 ; \mathrm{p}<0.01)$, whereas no differences were found in other curriculum parameters between the groups $(\mathrm{p}>0.05)$.

Conclusion: As a conclusion, the curriculums of the FD/C in foundation and state universities in Turkey were determined to show compliance with each other and with other countries.

Keywords: Bachelor degree education, curriculum analysis, physiotherapy and rehabilitation

\section{Introduction}

The physiotherapy profession, which has a 115-year history in the world, first emerged with the establishment of the Physiotherapy and Rehabilitation Department in Hacettepe University by honorary rector Prof. Dr. İhsan Doğramacı in 1961. In 1969, the Turkish Physiotherapy Association (TPA) was established as an association of physiotherapy profession in our country and became a member of the World Confederation of Physiotherapists in 1974 (1). After this, the first physiotherapy and rehabilitation faculty department/college (FD/C) in a foundation university (at Başkent University, Ankara) began Physiotherapy and Rehabilitation (PTR) education in 1993 (2). In 1991, TPA was accepted as a member of the European physiotherapists union (World Confederation for Physical Therapy-Europe) and ethical principles of the physiotherapy profession were published in our country in 1994 (3).

In Turkey, 64 universities have PTR FD/Cs to provide bachelor's degree PTR education, according to the 2014 records. In a recent study performed by Gürses et al. (4), most of these PTR FD/Cs (80.35\%) have been reported to have opened in the last four years. Some of these universities have started to provide education while some have not because of the lack of resources such as teaching staff, academic personnel, physical space, and so 
on. The Higher Education Board (HEB) is the auditor and approving authority for $\mathrm{FD} / \mathrm{Cs}$ in universities that provide bachelor's degree or post-graduate education in Turkey (5). Once a year, the HEB gives student quotas to the departments of universities to begin providing education. Today, approximately 3,400 physiotherapist candidates are taking their bachelor degree's education in PTR FD/Cs, which received permission to open and were granted student quotas in our country. Students who have completed a total of 12 years of elementary, secondary, and high school education are eligible for an examination that is performed by an official foundation of our country called the Measuring, Selection, and Placement Center (MSPC) to enter an FD/C of a university giving a four-year PTR bachelor's degree education (6).

In Turkey, whereas some of the universities are supported by the government, the others get their financial support from various private foundations (foundations, privately-owned institutions, etc.). The universities that are supported by the government are called "state universities", whereas the others called "foundation universities". Students who perform well the university entry exam and manage to enter a state university are not required to pay the tuition fee for the education. In foundation universities, students receive a bursary or pay a fee for education at different rates according to their performance in the university exam.

The aim of our study was to analyze and reveal the similarities and differences in curriculums of $\mathrm{FD} / \mathrm{Cs}$ providing PTR education in foundation and state universities.

\section{Methods}

Student quotas and PTR curriculums of FD/Cs in foundation and state universities were obtained from the HEC official website (Figure 1). The universities were divided into two groups-foundation (Group 1) and state (Group 2)-after the determination of the FD/Cs that were opened for PTR education.

The number of PTR FD/Cs numbers and student quotas in foundation and state universities for the past five years were calculated from the 2009 and 2014 Student Selection and Placement System (SSPS): Higher Education Programs and Quota Guidelines $(7,8)$.

Curriculum parameters examined from the official websites of FD/Cs are also given in Figure 1. The curriculum analyses of both groups were compared.

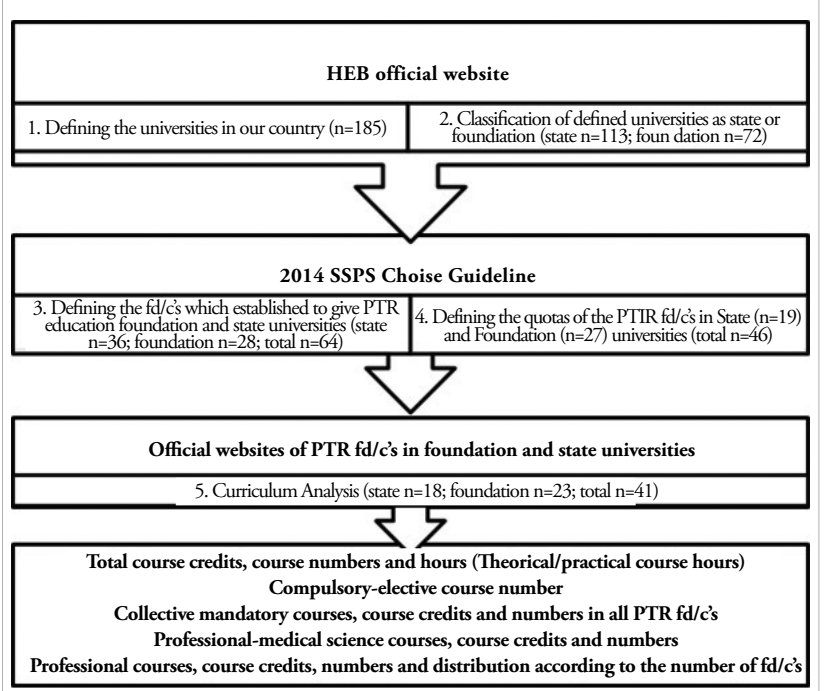

Figure 1. Study design and the parameters examined in curriculums

The exclusion criteria were as follows: a) PTR FD/Cs that were not given the student quotas by MSPC (a suborganization linked to the HEB) in 2014, and b) PTR $\mathrm{FD} / \mathrm{Cs}$ whose curriculums were not available in their official websites.

\section{Statistical analysis}

The Statistical Package for the Social Sciences (SPSS 15.0 Command Syntax, Chicago, Illinois, USA) was used for the statistical analysis of the collected data in our study. Descriptive statistics for the variables that were measurable were specified by the percentages, average, standard deviation, and minimum-maximum. Nonparametric Mann-Whitney U test was used for the comparison of curriculums of foundation and state universities. The statistical significance level $(\mathrm{p})$ was determined to be 0.05 .

\section{Results}

A total of 185 universities- 72 foundation and 113 statewere determined according to the data acquired from the HEB. 64 of these universities have been given the permission to provide PTR education by the HEB. It was found that of these, $36(56.25 \%)$ are state and 28 $(43.75 \%)$ are foundation universities. With regard to the data from the MSPC website, 46 of these FD/Cs (19 state [41.3\%] and 27 foundation [51.7\%]) were given student quota to begin providing education in the 2014-2015 academic year. Curriculums of 41 (89.1\%) (18 state [43.9\%] and 23 foundation [56.1\%] universities) out of $46 \mathrm{FD} / \mathrm{Cs}$ were reached through their own university websites. 
Table 1. Comparison of the curriculum parameters and student quotas between foundation and state universities

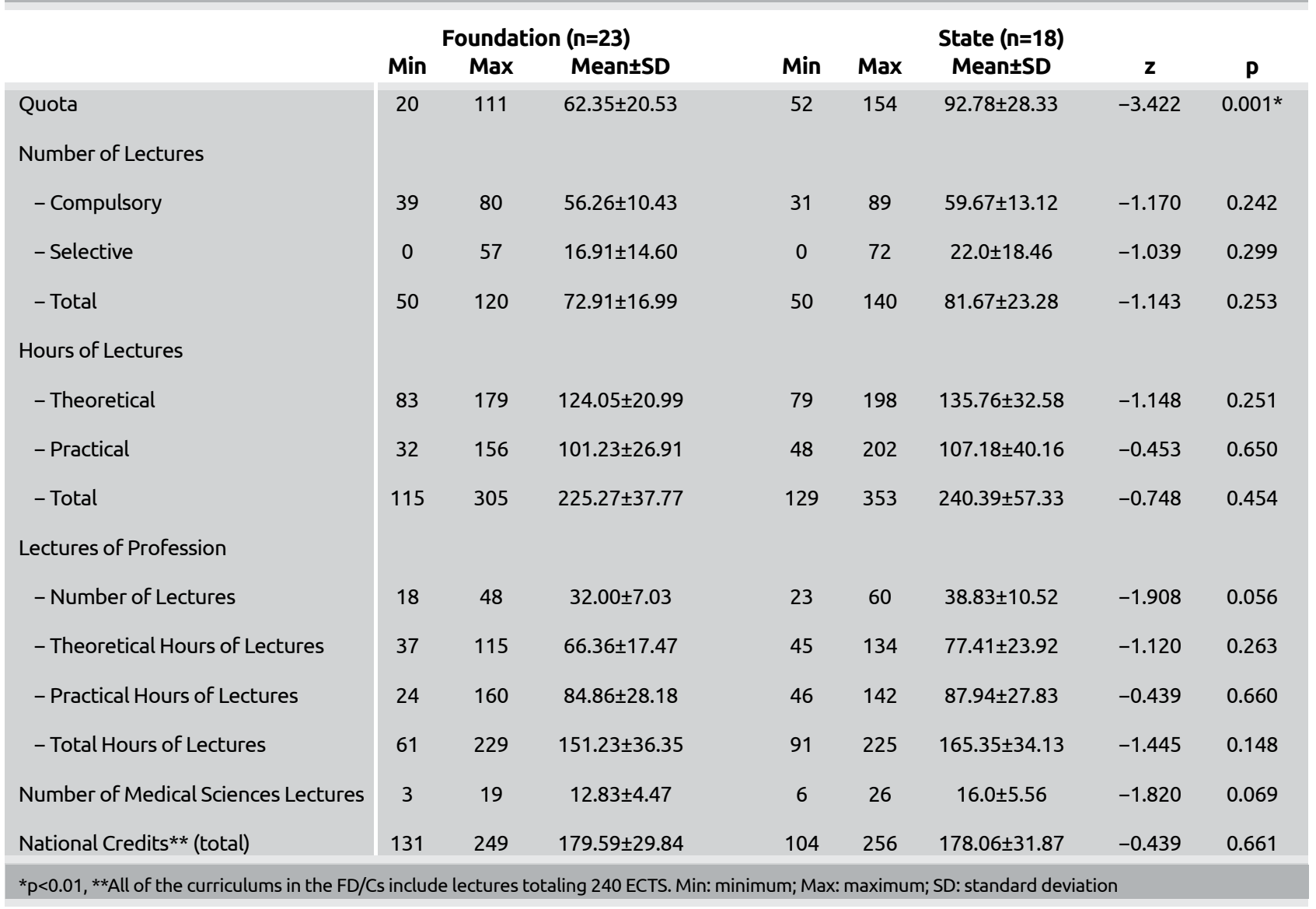

The student quotas, curriculum analysis, and comparison of curriculum parameters of the $41 \mathrm{FD} / \mathrm{Cs}$ in foundation and state universities were given in Table 1.

The student quotas showed a statistically significant difference between foundation and state universities among the data of $41 \mathrm{FD} / \mathrm{Cs}(\mathrm{z}=-3.422 ; \mathrm{p}<0.01)$. No statistically significant difference was found in the curriculum parameters between groups ( $p>0.05)$.

\section{Discussion}

Our study, which was planned to analyze the curriculums of foundation and state universities and put forth the similarities and differences between these groups, obtained and calculated the total number and hour of the lectures, number of lectures related to profession and medical sciences, total credits, and student quotas of the FD/Cs via their websites. The student quotas of state universities were found to be significantly higher than the foundation universities in Turkey. However, the curriculum parameters seemed compatible with
Most of the FD/Cs that received student quotas to provide PTR education in Turkey are from foundation universities. There has been an increase in the number of foundation universities; however, the student quotas given by the HEB to state universities are greater than that for foundation universities because of the higher number of academic staff and the earlier establishment of PTR FD/Cs in state universities. In a previous study by Gürses et al. (4), it was shown that at least one in $32 \mathrm{FD} / \mathrm{Cs}$ and all of the 191 instructors belong to FD/ Cs giving PTR education in Turkey. The number of instructors with a physiotherapy background changed between zero and $32(\mathrm{X}=4.54 \pm 6.18)$ per $\mathrm{FD} / \mathrm{C}$ and was $148(77.48 \%)$ in total. In the same study, the delivery of whole instructors in PTR FD/Cs were found to be between zero and five $(\mathrm{X}=1.22 \pm 1.58)$ per $\mathrm{FD} / \mathrm{C}$, and despite an increasing number of students, physiotherapistbackground full-time instructors were mean 4.54 per FD/C, which was inadequate. Even though more PTR $\mathrm{FD} / \mathrm{Cs}$ in state universities have received permission to provide physiotherapy education $(36 \mathrm{FD} / \mathrm{Cs}$ have permission but $19 \mathrm{FD} / \mathrm{Cs}$ started providing education) than foundation universities, the insufficient number of PTR instructors per FD/Cs and the lack of other sourc- 
es constitute an obstacle to start education in these FD/ Cs in Turkey. One of the criteria of the HEB to open a post-graduate program in a university is the number of instructors (at least three to open a master's degree and at least six for a PhD degree post-graduate program) (9, 10). The insufficient number of physiotherapist instructors in our country also has a negative effect, leading post-graduate education in PTR FD/Cs to be caught up in a vicious cycle.

The number of foundation universities that received permission to open an FD/C in the field of PTR is less than the state universities. This may have originated from the lack of enough space for training and other requirements that are necessary for a qualified education, as well as an inadequate number of instructors. Therefore, the student quotas of foundation universities remain less than state universities. The foundation universities are expected to solve these problems by increasing the number of instructors and structured space and by developing the quality and quantity of the materials for PTR education in the coming years through financial support greater than that for state universities.

The FD/Cs providing PTR education in foundation and state universities appear to be similar in terms of educational contents of their curriculums. The websites of the reference PTR FD/Cs of the world present their post-graduate curriculums and mostly discuss postgraduate education rather than providing and discussing their bachelor's degree curriculums in the literature. Therefore, our results related to bachelor's degree physiotherapy education curriculums (number of courses, credits, time, etc.) could not have been discussed with the literature.

In many countries, a specific systematic approach composes the physiotherapy education programs. When we analyze the PTR education in foreign countries from this perspective, in Sweden, the content of the physiotherapy programs must meet the quality criteria of the National Agency of Higher Education. Additionally, each university in Sweden has additional specific rules and criteria. All of the universities collaborate with each other every year to check the physiotherapy programs and update the curriculum. Finally, the curriculum is controlled by this national agency. In forming the educational programs and updating the curriculum, the feedback is taken from the instructors in the universities and clinicians/clinical supervisors working in the PTR area (11). In Australia, the Australian Universities Quality Agency defines the educational standards of FD/Cs and controls the quality of education and academic performance of the universities every five years. The Australian Physiotherapy Council accredits the students who graduate from entry-level physiotherapy programs to pass the practical area. National curriculum accreditation standards are determined by the Standards for Accreditation of Physiotherapy Educational Programs and the Australian Standards for Physiotherapy, and all the entry-level physiotherapy programs need meet the determined standards in to the minimum extent (12). Similarly, in the UK, physiotherapy education programs and the curriculum are seen to be standardized according to the framework drawn by the Health Professions' Council-Standards of Education and Training and the Charted Society of Physiotherapy-Curriculum Framework for Qualifying Programs institution. In addition to this, just as in the physiotherapy programs of Australian universities, the additional standards may exist in various extents in different universities of UK. Thus, graduates of physiotherapy programs are required to have the same level of knowledge, communication, and presentations and practical skills across the country (13). Even though the curriculums seem to be similar in foundation and state universities, the collaboration between the universities, the update and improvement of the curriculums under certain rules, and the control of a supervisory authority of these curriculums with certain intervals are urgent issues required to standardize the curriculums and determine the specific quality criteria of PTR programs in our country. Although, the curriculum standardization process of PTR FD/Cs in our country has not been completed yet, the curriculums of state and foundation PTR FD/Cs were found to be correlated with each other and generally showed compliance with other countries. For example, when the physiotherapy curriculum of the University College West, Esbjerg, Denmark, was analyzed, physiotherapy content of their curriculum was seen to be listed under four headings. These titles are as follows: physiotherapy theory and methods (projects, semester modules, modules for preparation and reflection upon clinical training, study planning, and guidance); manual tissue examination and manual treatment; sports; and electrotherapy and thermotherapy. The lectures of profession were intense, like in our country, during seven educational semesters under the electrotherapy (totaling 4.125 ECTS), manual tissue therapy (totally 13.875 ECTS), and sports (totally 12.75 ECTS) subheadings. The lectures of medical sciences, such as anatomy, physiology, psychology, neurology, rheumatology, and geriatrics 
(totaling 18 ECTS) were also found to be placed in their curriculums under "other health science courses" subheading (14), as done in our country. Crosbie et al. (15) reported that the inclusion of lectures on medical sciences, such as anatomy, physiology, biomechanics, psychology, and sociology in physiotherapy curriculums are important to understand the lectures related to profession and support the development of the clinical skills of students. According to "The Enphe: European Qualification Framework for Life Long Learning in Physiotherapy Final Report," which was published by European Network of Physiotherapy in Higher Education (ENPHE) in 2012, a candidate to become a physiotherapist should meet the criteria under the following headings: knowledge, skills, and general competence. These are listed because a candidate should document advanced knowledge about theories, assessments, and interventions for people with problems in movement and functioning; record critical understandings of theories and principles within the field of exercise and movement; demonstrate the advanced skills of reviewing documentation and communication of research in physiotherapy; exhibit advanced skills in the analyses of psychosocial, cognitive, emotional, and physical issues related to the patients/clients' dysfunction and situation; demonstrate advanced skills in implementing research- and clinical-based interventions within the fields of promotion, prevention, treatment/intervention, habilitation, and rehabilitation in physiotherapy; discuss the terms "evidence based" and "clinically based" knowledge; and take responsibility for developing the knowledge (16). When our curriculums were analyzed in light of this information, our bachelor's degree curriculums of PTR FD/Cs were determined to meet these requirements.

\section{Conclusion}

Ours is the first study that analyzes and compares the curriculums of the FD/Cs providing PTR education in universities in Turkey; it is original in terms of presenting an overview of physiotherapy education in our country. Detailed investigation of the physiotherapy programs in the bachelor's and post-graduate level would help identify the quality standards of the physiotherapy education as well as the requirements to meet these standards more objectively in Turkey.

Ethics Committee Approval: Ethics committee approval was not received for this study because the study was performed by using the freely available documents from the websites in internet and did not performed any interventional or non-interventional approach to any subject.
Informed Consent: Written informed consent is not needed for this study because the study was not performed on patients.

Peer-review: Externally peer-reviewed.

Author Contributions: Concept - H.N.G.; Design - H.N.G., İ.A.; Supervision - H.N.G., İ.A., M.T.; Resources - H.N.G., İ.A.; Materials - M.T.; Data Collection and/or Processing - M.T.; Analysis and/or Interpretation - H.N.G., İ.A.; Literature Search - H.N.G., İ.A., M.T.; Writing Manuscript - H.N.G., İ.A., M.T.; Critical Review - H.N.G., I.A., M.T.

Conflict of Interest: No conflict of interest was declared by the authors.

Financial Disclosure: The authors declared that this study has received no financial support.

\section{References}

1. Fizyoterapi \& Rehabilitasyon, Tarihçe ve Genel Tanıtım. [homepage on the Internet]. [updated 2009; cited 2015 July 07]. Available from: URL: http://www.istanbulbilim.edu.tr/ saglik-yuksekokulu-bolumlerimiz-fizyoterapi-ve-rehabilitasyon. php?sc $=\mathrm{d} \& \mathrm{~W}=1366$.

2. Başkent Üniversitesi. [homepage on the Internet]. [cited 2015 July 07]. Available from: URL: http://www.baskent.edu.tr/tarihce.php.

3. Türkiye Fizyoterapistler Derneği resmi web sitesi. [homepage on the Internet]. [updated 2012; cited 2015 July 07]. Available from: URL: http://www.fizyoterapistler.org/tarihce.aspx.

4. Gürses HN, Alemdaroğlu İ, Tanrıverdi M. Türkiye'de fizyoterapi ve rehabilitasyon fakülte bölümü/yüksekokullarının incelenmesi ve müfredat analizi. Turk J Physiother Rehabil 2014; 25: 16-27. [CrossRef]

5. Yükseköğretim Kurulu. [homepage on the Internet]. [cited 2015 July 07]. Available from: URL: http://www.yok.gov.tr/

6. 2014 ÖSYS: Öğrenci Seçme ve Yerleştirme Sistemi Kılavuzu. [homepage on the Internet]. [updated 2014; cited 2015 July 07]. Available from: URL: http://dokuman.osym.gov.tr/pdfdokuman/2014/YGS/2014_OSYS_KILAVUZU_02_01_2014.pdf.

7. 2009 Öğrenci Seçme ve Yerleştirme Sistemi (ÖSYS) Yükseköğretim Programları ve Kontenjanları Kılavuzu. [homepage on the Internet]. [updated 2014; cited 2015 July 07]. Available from: URL: http://osym.gov.tr/belge/1-11477/2009-osys-yuksekogretim-programlari-ve-kontenjanlari-ki-.html.

8. 2014 Öğrenci Seçme ve Yerleştirme Sistemi (ÖSYS) Yükseköğretim Programları ve Kontenjanları Kılavuzu. [homepage on the Internet]. [updated 2014; cited 2015 July 07]. Available from: URL: http://dokuman.osym.gov.tr/pdfdokuman/2014/OSYS/ Tercih/2014-OSYSKONTKILAVUZU14072014.pdf.

9. Yükseköğretim Kurulu, Yüksek Lisans Programı Açmak İçin Başvuru Formatt. [homepage on the Internet]. [cited 2015 July 07]. Available from: URL: http://www.yok.gov.tr/web/guest/icerik/-/journal_content/56_INSTANCE_rEHF8BIsfYRx/10279/\%2039778.

10. Yükseköğretim Kurulu, Doktora Programı Açmak İçin Başvuru Format1. [homepage on the Internet]. [cited 2015 July 07]. Available from: URL: http://www.yok.gov.tr/web/guest/icerik/-/journal_content/56_INSTANCE_rEHF8BIsfYRx/10279/\%2019003.

11. Hager-Ross C, Sundelin G. Physiotherapy Education in Sweden. Phys Ther Rev 2007; 12: 139-44. [CrossRef]

12. McMeeken J. Physiotherapy Education in Australia. Phys Ther Rev 2007; 12: 83-91. [CrossRef]

13. Bithell C. Entry-Level Physiotherapy Education in the United Kingdom: Governance and Curriculum. Phys Ther Rev 2007; 12: 145-55. [CrossRef] 
14. Professionshojkolen University College Syddanmark, Physiotherapy. Curriculum For The Course In Physiotherapy In Esbjerg, Denmark, Chapter 2: Course Content 2001: 14-32.

15. Crosbie J, Gass E, Jull G, Morris M, Rivett D, Ruston S, et al. Sustainable undergraduate education and Professional competency. Aust J Physiother 2002; 48: 5-7. [CrossRef]
16. The European Network of Physiotherapy in Higher Education (Enphe): European Qualification Framework for Life Long Learning in Physiotherapy Final Report, Towards a qualification framework culture, ENPHE, Enschede, Netherlands, October 2012. [homepage on the Internet]. [updated 2015; cited 2015 July 07]. Available from: URL: http://www.ENPHE.org/. 